\title{
PSYCHIATRIC HARM AND THE INVOLUNTARY PARTICIPANT: "A STORY OF THE EBB AND FLOW OF TORT LIABILITY"
}

(Case commentary: From Dooley v Cammell Laird \& Co Ltd and Mersey Insulation Company Ltd through to W $\mathrm{v}$ Essex County Council and Salter v UB Frozen and Chilled Foods Ltd.)

\author{
Vivien Pickford, Senior Lecturer in Law, Portsmouth Business \\ School, University of Portsmouth*
}

\section{Introduction}

Claimants seeking damages in an area of law which has been variously described as "a patchwork quilt of distinctions which are difficult to justify" and one where "the common law has taken a wrong turn" face particular challenges. Certain categories of claimant who had been treated more favourably than others appeared to lose their special status following the House of Lords' decision in White v Chief Constable of South Yorkshire Police $^{4}$ but more recent decisions suggest that this may not be so with regard to litigants claiming as involuntary participants. This commentary traces the development of the law with regard to such claimants and considers the impact of recent cases.

\section{Recognising the Category of Involuntary Participant}

The civil courts have always been presented with difficulties when determining claims in negligence for pure psychiatric harm, battling in particular with the "floodgates argument" and a complex, progressing area of medicine. Development of the law has therefore been slow and initially a claimant needed to be able to prove that he had been in reasonable fear for his own safety in order to succeed. ${ }^{5}$ Hambrook v Stokes Bros ${ }^{6}$ represented the first successful claim by a secondary victim, a mother who was in no physical danger herself but who reasonably feared for the safety of her children. She was not categorised as such in the judgments and neither was there any attempt to categorise the claimant in Dooley $v$ Cammell Laird \& Co Ltd and Mersey Insulation Company $\mathrm{Ltd}^{7}$ which is generally

\footnotetext{
* I am grateful to Professor Maniruzzaman and to Adele Sinclair, at Portsmouth Business School, for their helpful comments on an earlier draft of this article.

1 Taken from White v Chief Constable of South Yorkshire Police [1999] 2 AC 455, at 503 per Lord Hoffman

2 ibid., at 500 per Lord Steyn.

3 Law Commission No. 249 Liability for Psychiatric Illness para.4.2.

4 Op cit. n.1.

5 Dulieu v White \& Sons [1901] 2 KB 669.

6 [1925] 1 KB 141.

7 [1951] 1 Lloyd's Rep 271.
} 
acknowledged to be the first case involving a successful claim by an involuntary participant. Dooley was a crane-driver who suffered psychiatric harm when the defective rope on his crane broke, causing the load to crash into the hold of a ship where his fellow employees were working. The decisions in both cases were based on psychiatric harm being reasonably foreseeable. ${ }^{8}$

The distinction between different categories of claimant was first highlighted by Lord Oliver in Alcock v Chief Constable of South Yorkshire Police, ${ }^{9}$ a case arising out of the Hillsborough disaster. Unlike previous cases, there were potentially a large number of claimants so that "floodgates" was a particular issue. Lord Oliver famously stated that broadly claimants could be divided into two categories; "those cases in which the injured plaintiff was involved, either mediately or immediately, as a participant, and those in which the plaintiff was no more than the passive and unwilling witness of injury caused to others." 10

Lord Oliver's examples of those falling into the first of these categories and therefore a primary victim or equivalent included rescuers and those where:

“. . . the negligent act of the defendant has put the plaintiff in the position of being, or of thinking that he is about to be or has been, the involuntary cause of another's death or injury and the illness complained of stems from the shock to the plaintiff of the consciousness of this supposed fact."."11

He thereby provided the involuntary participant with special status and gave Dooley as one of his examples. In Dooley there was in fact no indication that the claimant blamed himself for what happened and neither was there a primary victim other than Mr. Dooley himself as fortuitously none of his colleagues was injured. ${ }^{12}$ Lord Oliver, however, also opined that:

"The fact that the defendant's negligent conduct has foreseeably put the plaintiff in the position of being an unwilling participant in the event establishes of itself a sufficiently proximate relationship between them and the principal question is whether, in the circumstances, injury of that type to that plaintiff was or was not reasonably foreseeable."13

8 Dooley recovered damages in negligence against the owner of the defective rope but also recovered damages for breach of statutory duty against his employers, Cammell Laird.

9 [1992] AC 310

10 ibid., at 407.

11 ibid., at 408 .

12 This is in contrast to his Lordship's other examples of Galt $\mathrm{v}$ British Railways Board (1983) 133 NLJ 870 and Wigg v British Railways Board The Times, 4 February 1986, unreported, both involving train drivers who did wrongly think that they were responsible for killing or injuring persons. The brief account of Wigg additionally uses language appropriate to a rescuer trying to help the primary victim and so it could be argued that the claimant fell into that special category also afforded special status by Lord Oliver.

13 Op cit. n.9, at 408 
Mr. Dooley was certainly an "unwilling participant" and Lord Oliver's judgment emphasised the significance of being such a claimant in that the proximity requirement was satisfied. In contrast "a passive and unwilling witness" 14 or secondary victim was and still is faced with a number of control factors in order to establish a duty of care owed to him, one of which is proximity specifically in terms of closeness of relationship to the victim, closeness in time and space to the incident and the means by which the shock was caused. ${ }^{15}$ It is the first element of this proximity test which is the most likely stumbling block for an involuntary participant if he were not to be classified as primary or of equivalent status.

Subsequent cases such as Robertson and Rough v Forth Road Bridge Joint Board $^{16}$ recognised the position of the involuntary participant and distinguished him from a bystander who "was not directly involved in it as the actor by whose hand the death or injury was caused to the third party". ${ }^{17}$ Perhaps the words "or the reasonably imagined death or injury" should have been added in view of Lord Oliver's examples. Further, the emphasis then appeared to be on the feeling of responsibility for what occurred, despite this not being the case in Dooley itself. The pursuers in Robertson therefore failed in their claim. Although they and their fellow employee, who was killed when he was blown off the Forth bridge, had all been engaged on the same task in the course of their employment at the time of the incident, it was natural forces which had caused it and they were aware of that.

Arguably more difficult to understand is the decision in Hunter v British Coal Corporation. ${ }^{18}$ The claimant was driving a truck underground and hit a water hydrant which was protruding into the roadway through the defendant's negligence. He and a colleague unsuccessfully attempted to stop the flow of water and so he then searched for a hosepipe to divert the flow. Whilst he was some 30 metres away he heard the hydrant explode and then about ten minutes later a message was given out to the effect that a man had been injured. As he walked back towards the scene he was told that his colleague was dead. His claim for damages for psychiatric harm was unsuccessful; it was held that he was not an involuntary participant as he was not present at the scene of the accident. Further his subsequent illness was described as an abnormal reaction, caused by an irrational feeling of responsibility and therefore unforeseeable. Lord Hobhouse, however, who dissented, found Lord Hope's judgment referred to above in Robertson to be the most "illuminating contribution"19 to the question of whether in the circumstances psychiatric harm to the claimant was reasonably foreseeable. Concern was expressed by the majority that the law should not provide compensation for a survivor's guilt but it would seem that it was not simply because he survived, and his colleague did not, that Hunter suffered his illness but because he genuinely felt responsible for his colleague's death as he had hit the hydrant. The defendants conceded that if Hunter had

14 ibid., at 407 per Lord Oliver.

15 Other control factors include the shock requirement and that psychiatric harm be reasonably foreseeable in a person of normal fortitude.

16 [1995] IRLR 251.

17 ibid., at 255 per Lord Hope.

18 [1999] QB 140.

19 ibid., at 165 . 
witnessed his colleague being killed then they would have been liable However, Dooley does not and cannot require that the claimant actually sees the death or injury to the third party as no-one else suffered any harm in that case. Mullany questions "On what sound basis can the coal miner worker be denied recovery for proven psychiatric injury sustained on learning of the death of a colleague on site with whom he was working shortly beforehand?"20 The answer must surely be that there is none.

In Hunter Lord Hobhouse made reference to the Law Commission Consultation Paper ${ }^{21}$ and its Report on Liability for Psychiatric Illness ${ }^{22}$ was published shortly afterwards. It recommended that the involuntary participant should be entitled to recover, acknowledging that the floodgates objection would not apply in such cases and that medical literature supported such inclusion. ${ }^{23}$ It considered that there should be a special rule as set out by Lord Oliver applicable to involuntary participants and saw no reason to restrict their existing rights. ${ }^{24}$ Of particular interest is the use of the phrase "special rule" indicating that such claimants were regarded as being in a category of their own and this is supported by the Commission's recommendation that:

"Although a legislative provision on this would not be appropriate, we tend to the view that the courts should abandon attaching practical significance, in psychiatric illness cases, to whether the plaintiff may be described as a primary or a secondary victim". ${ }^{25}$

Regrettably this has not happened; instead the categorisation of primary and secondary victims has become crucial to the determination of liability.

\section{Muddying the Waters}

The decision of the House of Lords in Page v Smith ${ }^{26}$ a case involving a participant in an accident who suffered only psychiatric harm, did not on the facts appear to be particularly relevant in terms of distinguishing between primary and secondary victims. The claimant was obviously primary being directly involved in the accident. However the repercussions of this decision are considerable. It made the distinction between primary and secondary vital, determining that a primary victim does not have to show that psychiatric illness was foreseeable in a person of normal fortitude; reasonable foreseeability of personal injury is sufficient. Thus it "dethroned foreseeability of psychiatric injury from its central position as the unifying feature of this branch of the law" ${ }^{27}$ attracting considerable criticism. ${ }^{28}$ It also

20 "English Psychiatric Injury Law - Chronically Depressing" (1999) 115 LQR 30 at 31.

21 Consultation Paper No. 137, Liability for Psychiatric Illness.

22 Op cit. n.3.

23 ibid., para.7.6.

24 ibid., para.7.5.

25 ibid., para.5.54.

26 [1996] 1 AC 155.

27 Op cit. n. 1 at 475 per Lord Goff. 
blurred that vital differentiation. Lord Lloyd, for example, described Lord Oliver's distinction as being "the most convenient and appropriate terminology" 29 but then adopted a narrower classification by describing a secondary victim as one who is "almost always outside the area of physical impact". ${ }^{30}$ Other judges in Page used alternative terminology such as participant and bystander, ${ }^{31}$ and participant and non-participant, ${ }^{32}$ and there was no discussion, for example, of Dooley.

The necessity for clarity was provided in White v Chief Constable of South Yorkshire Police, ${ }^{33}$ another complex House of Lords' decision, which like Alcock arose out of the Hillsborough disaster. It was, however, arguably to bring the law full circle for claimants such as rescuers and involuntary participants. Emphasis was once again placed on physical injury or reasonable fear therefore and White may therefore be seen as a backward step in the development of the law in this area.

Having allowed none of the friends or relatives of the victims to succeed in their claims for psychiatric harm in Alcock, their Lordships were reluctant to find in favour of the police officers claiming in White. They had succeeded in the Court of Appeal ${ }^{34}$ on the basis that they were "quasi-employees" 35 of the tortfeasor, or rescuers, or both and therefore primary victims. The majority of their Lordships, however, considered employee witnesses to be in no better position than other bystanders. ${ }^{36}$ Further they determined that rescuers, as such, were not primary victims. This was despite such claimants, like involuntary participants, having been identified by Lord Oliver as examples of primary victims, and despite the supportive conclusions of the Law Commission. The majority interpreted Page as restricting the definition of primary victim to those who were either in danger of physical injury or who reasonably believed themselves to be so endangered. ${ }^{37}$ As none of the claimants could satisfy that definition or, as secondary victims, prove a closeness of relationship to those physically injured or killed, they all failed in their claims.

It can be strongly argued that this is a misinterpretation of Page and that whilst it provides us with an example of a victim who is primary, because he was actually involved in the crash and in reasonable fear of being injured, it does not restrict the primary category to such claimants. Being within the range of foreseeable physical injury is, as Cooke comments, "a sufficient condition of liability for psychiatric injury but not a necessary condition of

28 See, e.g. Trindade, "Nervous Shock and Negligent Conduct" (1996) 112 LQR 22, Teff, "Liability for Negligently Inflicted Psychiatric Harm: Justifications and Boundaries" (1998) 57(1) CLJ 91.

29 Op cit. $\mathrm{n} .26$ at 184.

30 ibid., at 187.

31 ibid., at 178 per Lord Jauncey.

32 ibid., at 182 per Lord Browne-Wilkinson.

33 Op cit. n.1.

34 Frost v Chief Constable of South Yorkshire [1998] QB 254.

35 Police officers are holders of an office rather than employees.

36 This may be contrasted with cases where the employee suffers direct psychiatric harm such as Barber v Somerset County Council [2004] 2 All ER 385.

37 Lord Goff dissented on this issue. 
such liability". ${ }^{38}$ Indeed Lord Lloyd himself in the leading judgment in Page concluded with a number of propositions but made no reference therein to determining who is a primary victim. ${ }^{39}$

It was not, in any event, necessary on the facts of Page to answer that question; the distinction was only relevant in deciding the effect of such categorisation. White however is very much a policy decision ${ }^{40}$ and signalled bad news in particular for claimants such as rescuers and involuntary participants. It seemed to leave them in an impossible position; having to prove physical danger or reasonable fear thereof, in which case they would simply be primary victims anyway, or a close relationship with the victim which would be most unlikely. In effect the decision appeared to destroy such special categories of claimants.

\section{Turning the Tide}

This area of law has been dominated by the Hillsborough litigation and its policy decisions placing the judiciary in a difficult position when faced with claims for psychiatric harm arising out of very different circumstances. Maybe this was foreseen by Lord Hoffman in White when he made reference to Dooley, Galt and Wigg and commented that "there may be grounds for treating such a rare category of case as exceptional and exempt from the Alcock control mechanisms" ${ }^{41}$ Such a case came before the House of Lords in 2000. In $W$ v Essex County Council ${ }^{42}$ parents claimed inter alia damages for psychiatric harm caused by the negligence of the council and its social worker. The claimants had four young children and were approved as specialist adolescent foster carers by the council. They made it clear that they would not accept a child who was a known or suspected sexual abuser but such a boy was placed with them. The boy abused the claimants' children and both the claimants and their children suffered psychiatric harm. The children's claims proceeded but those of the parents were struck out by the trial judge, ${ }^{43}$ a decision which was upheld by the Court of Appeal, ${ }^{44}$ on the basis that they were secondary victims and could not satisfy the Alcock control factors. Their appeal to the House of Lords succeeded however.

One of the arguments advanced by the parents was that they felt "they had participated in or contributed to or laid the foundation for the commission of the acts of abuse on their children "45 by arranging for the boy to be brought into their home and that they were therefore primary victims. In the leading judgment Lord Slynn recalled "the need for flexibility in dealing with new situations not clearly covered by existing decisions", ${ }^{46}$ which had been

38 "Primary Victims: The End of the Road?" (2004) 25 Liverpool Law Review 29 at 35.

39 Op cit. n.26 at 197.

40 Policy motives are freely discussed by both Lord Steyn at 498 and Lord Hoffman at 510 .

41 Op cit. n. 1 at 508 .

42 [2001] 2 AC 592.

43 [1997] 2 FLR 535, Hooper J.

44 [1999] Fam 90.

45 Op cit. n.42 at 599 per Lord Slynn.

46 ibid., at 600. 
recognised by Lord Scarman in McLoughlin v O'Brian. ${ }^{47}$ More surprisingly he considered "the categorisation of those claiming to be included as primary or secondary victims is not as I read the cases finally closed. It is a concept still to be developed in different factual situations." 48 He further stated that none of the relevant cases to which he had been referred conclusively showed that if the parents' injury flowed from a feeling of responsibility they were prevented from being primary victims and cited Lord Oliver in Alcock. ${ }^{49}$ He therefore allowed the appeal and Lord Steyn, one of the majority in White, and Lord Hope both concurred..$^{50}$

Perhaps therefore the door had always been left slightly ajar for claims by involuntary participants but $W$ makes their position stronger and was relied on in the recent Scottish case of Salter $v$ UB Frozen and Chilled Foods Ltd. ${ }^{51}$ The pursuer was employed by the defenders in its factory as a forklift truck driver and during stocktaking he lifted his workmates in a cage mounted onto the truck to check the stock on the rows of pallets, some of which were close to the roof structure of the warehouse. They wore helmets and at the highest level had to duck from time to time to avoid the beams. Tragically, one of the stock-takers was fatally injured when he hit his head on a cross-member. The pursuer, who was unable to see his workmates when they were working at that level, was aware that his truck had shuddered at one point. He then saw a helmet fall to the ground and as he moved the truck, on the instructions of the other stock-taker, he saw blood dripping from the cage and then the body of the stock-taker, bleeding from various orifices. He blamed himself for the accident and was subsequently diagnosed as suffering from post traumatic stress disorder and depression.

The defenders sought dismissal of the pursuer's claim for damages in negligence arguing that he was not a primary victim as he was not in physical danger or reasonable fear thereof and he did not satisfy the secondary control mechanisms. ${ }^{52}$ The trial judge, however, held the pursuer to be a primary victim because he was actively involved in the accident, although not himself to blame; the real cause was the unsafe working practices of the defenders. The judge commented that it was not expressed in any of the authorities cited to him that Dooley had been wrongly decided; the facts were similar and perhaps stronger as Mr. Dooley had not blamed himself, and it was "at the very least arguable that, having regard to the authorities and in particular Dooley and the subsequent treatment of that case, psychiatric injury was, on the assumed facts, reasonably foreseeable". ${ }^{53}$

Arguably Salter does not sit comfortably with White but neither do various obiter dicta statements by members of the House of Lords referred to above. The fundamental problem in this area of law is the requirement to categorise claimants as either primary or secondary and the way in which that classification was restricted in White. Whilst the desire to prevent liability

[1983] 1 AC 410 at 430

48 Op cit. n.42 at 601.

49 ibid.

50 The action was finally settled out of court.

512003 SLT 1011.

52 The defenders also argued that the action was time barred.

53 Op cit. n.51 at 1019. 
extending too widely in cases involving pure psychiatric harm may be understandable, a "one size fits all" approach is particularly inappropriate in cases like Dooley and Salter where there is no fear of "floodgates" anyway. Further, it has arguably produced some unjust decisions even where there is such concern, as demonstrated by Alcock itself. It has already been noted that the Law Commission recommended amendments to the law, such as abandoning attaching practical significance to such classification ${ }^{54}$ and since Salter the Scottish Law Commission has also reported, ${ }^{55}$ proposing various changes including the abolition of the "classification as such of persons into primary and secondary victims". ${ }^{56}$

Its draft bill distinguishes between those suffering mental harm because of what directly happened to them and others who were not directly involved. It is made clear in the explanatory notes that the former would include not only those at risk of physical harm but also "persons who were involved in such a way as to feel personally responsible for it, even though they were not at fault". ${ }^{57}$ The defender would, however, only be liable to such persons if the harm amounted to a medically recognised mental disorder and it was reasonably foreseeable that the act was likely to cause a person in the victim's position to suffer such harm. Additional criteria would have to be satisfied by those not directly involved, unless a rescuer. ${ }^{58}$ The proposed legislation would therefore place a pursuer like Mr Salter in the first category but what about someone like Mr. Dooley who did not argue that he felt personally liable? He too should be able to argue that he falls into that category as he was directly involved. The recommendations of neither Law Commission go as far as advocating a single test of reasonable foreseeability but the decision in Salter caused Kinloch to question:

“. . . whether the complex primary and secondary victims categorisation with which the courts have to struggle really represents any advance in analysis over the simple reasonable foreseeability test applied all those years ago in the first of the important nervous shock cases to arise in Scotland, Bourhill v Young, 1942 SC (HL) 78". ${ }^{9}$

It cannot be denied that such categorisation has caused more problems than it has solved in cases where "floodgates" is not an issue. However the courts would struggle with a single reasonable foreseeability test where there are, potentially, many claimants. In such cases they are still awaiting "a coherent, logical and just set of principles". ${ }^{60}$

\section{Conclusions}

Members of the judiciary, of the Law Commissions for both England and Wales and Scotland, and academics continue to be critical of this area of law and in particular the division of claimants into primary and secondary

54 Op cit. n.25.

55 Scottish Law Commission No.196, Report on Liability for Psychiatric Illness.

56 ibid., para.3.3.

57 ibid., at 52.

58 ibid., Reparation for Mental Harm (Scotland) Bill [Draft] s.4.

59 "Salter v UB Frozen and Chilled Foods Ltd" (2003) 33 SLTA 261 at 262.

60 Op cit. n.29, Trindade at 27. 
victims. Further, whilst some would argue that at least the boundary between them was clarified in White, others consider the distinction to be far from clear. Many comment too that the law is still evolving and particular examples of this include not only issues such as what constitutes "immediate aftermath" 61 but also, of particular relevance to this commentary, what is arguably an extension of the category of primary victim. Claimants who were not in physical danger or reasonable fear thereof have, in certain circumstances, been held to be primary, despite the decision in White. Thus a father who was wrongly informed that his baby had died and was given what he understood to be his dead baby to hold was classified as primary ${ }^{62}$ and so too was a person who claimed to have been falsely imprisoned because of his solicitor's negligence. ${ }^{63}$ It is not therefore only the involuntary participant who has presented the courts with difficult decisions regarding status. All these examples reinforce the conclusion that the law in this area has been too much driven by the Hillsborough decisions, largely determined by policy, and that the Alcock classification of victims is inappropriate in cases which do not result from large-scale tragedies. The "fear of floodgates" is not then an issue, and where the claimant is directly involved, although not in physical danger himself, he should not be treated as a secondary victim.

Dooley, which has never been expressly overruled, was determined on the basis of psychiatric harm being reasonably foreseeable and there is a strong argument for returning to this approach, at least in the case of an involuntary participant, and indeed other claimants directly involved in the incident, and not classifying them as either primary or secondary. This would surely mark a return to principle, the search for which was called off, according to Lord Hoffman in White. 64

Such an approach would, in practice, achieve the same result as that recommended by the Law Commission with regard to involuntary participants ${ }^{65}$ and is reminiscent of Lord Bridge's judgment in McLoughlin v $O^{\prime}$ Brian, ${ }^{66}$ another case involving only one claimant. He opined that the defendant's duty "must depend on reasonable foreseeability" and must be judged on a case-by-case basis rather than being pre-determined by a fixed category. ${ }^{67}$ The Scottish Law Commission's recommendations applicable, amongst others, to involuntary participants also refer to reasonable foreseeability of a medically recognised mental disorder ${ }^{68}$ as being all that is required in such cases. Unless these draft bills become law it will be left to the judiciary to seek a way forward and it is submitted that cases like $W$ and Salter represent a small step in the right direction.

61 Galli-Atkinson v Seghal [2003] EWCA Civ 697.

62 Farrell v Avon Health Authority [2001] Lloyd's Rep Med 458.

63 Mcloughlin v Jones [2002] 2 WLR 1279.

${ }^{64}$ Op cit. n.1, at 511.

65 Op cit. n.3, para..7.6.

66 Op cit. n.47.

67 ibid., at 443.

68 Op cit. n.55. The additional requirement that it be reasonably foreseeable that the act in question was likely to cause a person in the position of the victim to suffer harm of that kind is to clarify that there would be no requirement that the wrongdoer foresaw or was aware of the existence of the victim. This would be unlikely to be the position anyway in the case of an involuntary participant. 